Available online on 15.05.2018 at http://jddtonline.info
Journal of Drug Delivery and Therapeutics
Open Access to Pharmaceutical and Medical Research
$\begin{gathered}\text { 2011-18, publisher and licensee JDDT, This is an Open Access article which permits unrestricted } \\ \text { non-commercial use, provided the original work is properly cited }\end{gathered}$

Open $\odot$ Access

Research Article

\title{
PHENOLIC, FLAVONOID AND TANNIN CONTENT DETERMINATIONS AND IN-VITRO ANTI-OXIDANT ACTIVITY OF ROOT EXTRACTS OF SACCHARUM MUNJA ROXB.
}

\author{
Baghel RK ${ }^{1 *}$, Srivastava $\mathrm{AK}^{2}$, Gohil $\mathrm{KJ}^{2}$, Kaushik $\mathrm{D}^{\mathbf{1}}$ \\ ${ }^{1}$ Agra Public Pharmacy College, Agra, Uttar Pradesh-282007, India \\ ${ }^{2}$ Anand College of Pharmacy, Keetham, Agra, Uttar Pradesh-282007, India
}

\section{ABSTRACT}

Free radicals are reactive molecules involved in many physiological processes and have been associated with many diseases, such as ageing, cancer, arthritis, liver injury and cardiac complications. The fact between anti-oxidant potential and amount of polyphenolics compounds of Saccharum munja is very crucial co-relation because of its ehnomedicnal uses and experimental values. The total phenolics content were found to be $10.15 \pm 2.45 \mathrm{mg}$ gallic acid equivalent (GAE)/g total flavonoids contents and total tannin contents were $11.34 \pm 1.20 \mathrm{mg} \mathrm{RE} / \mathrm{g}$ and $14.54 \pm 0.52 \mathrm{mg}$ GAE$/ \mathrm{g}$ respectively of Saccharum munja. The ability of Saccharum munja root extract was found to inhibit reactive oxygen species (ROS) free radicals. In the present study, the relative antioxidant ability of Saccharum munja was investigated through two in-vitro models, such as antioxidant capacity by radical scavenging activity using, $\alpha$, $\alpha$-diphenyl- $\beta$-picrylhydrazyl (DPPH) and nitric oxide (NO) methods. The extracts were used at concentration 20, 40, 60, 80 and $100 \mu \mathrm{g} / \mathrm{ml}$ concentrations and radical scavenging activity was determined in terms of inhibition percentage. The IC $_{50}$ (concentration required for $50 \%$ inhibition) were calculated for each radicals. The In-vitro free radical DPPH activities was found to $73.45 \pm 0.25$ and NO antioxidant activity were found to be $57.20 \pm 1.15$ at maximum concentration of $100 \mu \mathrm{g} / \mathrm{ml}$. This study proven the significant role of hydro-alcoholic extract of Saccharum munja Roxb. as a potential source of natural antioxidants.

Keywords: polyphenolic, anti-oxidant, free radical etc.

Article Info: Received 10 Feb, 2018; Review Completed 27 April 2018; Accepted 30 April 2018; Available online 15 May 2018

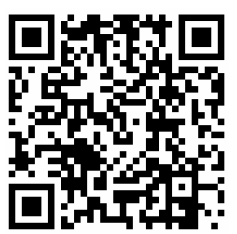

Cite this article as:

Baghel RK, Srivastava AK, Gohil KJ, Kaushik D, Phenolic, flavonoid and tannin content determinations and in-vitro anti-oxidant activity of root extracts of Saccharum munja roxb. , Journal of Drug Delivery and Therapeutics. 2018; 8(3):93-95 DOI: http://dx.doi.org/10.22270/jddt.v8i3.1712

*Address for Correspondence: Raj Kumari Baghel, Agra Public Pharmacy College, Agra, U.P., India

\section{INTRODUCTION}

Climatic changes are giving rise to a variety of free radicals, in which plants have to deal with them in order to survive. Many reactive oxygen species, such as singlet oxygen, superoxide ion, hydroxyl ion and hydrogen peroxide, are highly reactive, toxic molecules, which are generated normally in cells during metabolism. They cause severe oxidative damage to proteins, lipids, enzymes and DNA by covalent binding and lipid peroxidation, with subsequent tissue injury. Natural antioxidant agents have attracted much interest because of their ability to scavenge free radicals. ${ }^{1-2}$

Saccharum munja (sar) root is sweet acrid, cooling, aphrodisiac useful in burning sensation thirst, erysipelas blood troubles, liver, urinary complains, eye disease and is a good source of polyphenolics. ${ }^{3}$

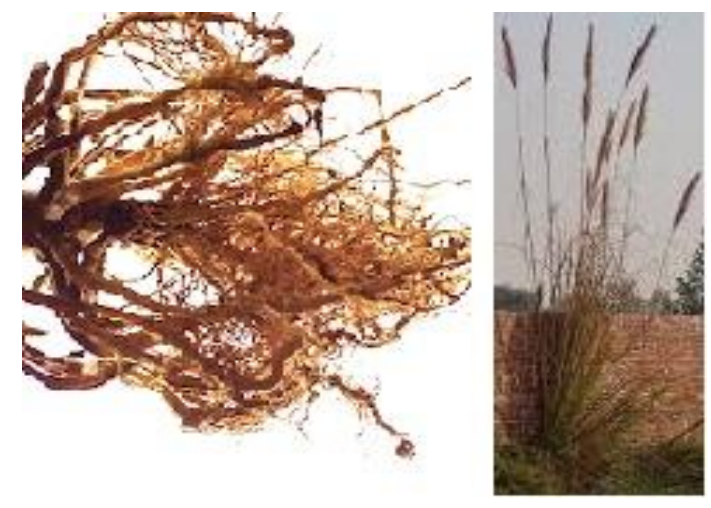

Figure 1: Morphology of (a) root (b) entire plant 


\section{MATERIAL AND METHODS}

\section{Collection and preparation}

The medicinal plant material was collected from different geographical area of district Agra, Uttar Pradesh, India. The medicinal plant was authenticated from National Institute of Science Communication and Information Research (NISCAIR), New Delhi, India under supervision of scientist Dr. Sunita Garg.

\section{Plant Extraction}

The plant part was dried for two weeks under shade, then at room temperature and were subjected to size reduction with a crusher and then passed through sieve no. 40 to get uniform powder. Around $250 \mathrm{~g}$ of powdered plant material was subjected to extraction with solvent such as petroleum ether (for the purpose of defatting), alcohol (60\%). The hydro-alcoholic (40:60) extracts were subjected for maceration process of cold extraction. The extract was then distilled to dryness under reduced pressure using rotatory evaporator to yield the respective dried extract. ${ }^{4}$

\section{Determination of Total Phenolic Content:}

The total phenolic content of the plant extract was determined by the Folin-Ciocalteu method

Quantitative analysis/total phenolic content of plant was performed by Spectrophotometric method and determination was done on the basis of a standard curve of gallic acid. Absorbance of the standards (Gallic acid and Ascorbic acid) were measured at $765 \mathrm{~nm}$ using UV/VIS spectrometer (Shimadzu, Japan) against blank, i.e., distilled water ${ }^{5}$. The total phenolic content of plant extract displayed in figure 2 .

\section{Determination of Flavonoid Contents:}

Individual plant extract of $1 \mathrm{~g}$ with aluminium chloride for determination of flavonoids content was performed $^{6 .}$ The total flavonoid content of plant extract displayed in figure 2 .

\section{Determination of Tannin Content}

The tannin was determined by Folin-Ciocalteu method. Absorbance for test and standard solutions were measured against the blank at $725 \mathrm{~nm}$ with an UV/Visible spectrophotometer. ${ }^{7}$ The tannin contents were expressed in (table 2) terms of $\mathrm{mg}$ of GAE/g of extract.

\section{In-vitro antioxidant Activity}

\section{DPPH Test}

The ability of individual plant extracts to scavenge the $\mathrm{DPPH}^{\circ}$ radicals were assessed by using given method. ${ }^{8}$ The stable DPPH radical was used for determination of free radical scavenging activity of test sample..$^{9-10}$ The absorbance was recorded at $517 \mathrm{~nm}$ using UV/Vis spectrophotometer against blank (using methanol). The measurements were taken thrice, and scavenging effect was calculated based on the percentage of DPPH scavenged. $^{11-12}$

\section{Nitric oxide scavenging activity}

Nitric oxide radical generated from sodium nitroprusside was measured. ${ }^{13}$ Briefly, the reaction mixture $(5.0 \mathrm{~mL})$ containing sodium nitroprusside $(5$

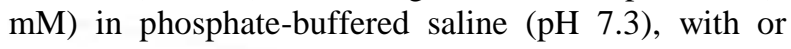
without plant extract at different concentrations, were incubated at $25^{\circ} \mathrm{C}$ for 3 hours. The nitric oxide radical thus generated and reacted with oxygen to produce the nitrite ion, which was assayed and incubated at 30minute intervals by mixing $1.0 \mathrm{~mL}$ incubation mixture with an equal amount of Griess reagent. The absorbance of the chromophore (purple azo dye) formed during the diazotization of nitrite ions with sulfanilamide and subsequent coupling with naphthylethylene di-amine di-hydro chloride (NEDD) was measured at $546 \mathrm{~nm}^{15-17}$ (Table 2)

\section{RESULTS AND DISCUSSION}

\section{Total Phenolic, Flavonoids \& Tannin Contents:}

Phenolic compounds have redox properties, which allow them to act as antioxidants. As their free radical scavenging ability is facilitated by their hydroxyl groups, the total phenolics concentration could be used as a basis for screening of anti-oxidant activity. The polyphenolics are plant secondary metabolites, the antioxidant activity of which depends on the presence of free $\mathrm{OH}$ groups, especially $3-\mathrm{OH}$. The total phenolics content was $10.15 \pm 2.45 \mathrm{mg}$ gallic acid equivalent (GAE)/g, total flavonoids contents and total tannin contents were $11.34 \pm 1.20 \mathrm{mg} \mathrm{RE} / \mathrm{g}$ and $14.54 \pm 0.52 \mathrm{mg}$ $\mathrm{GAE} / \mathrm{g}$ respectively shown in figure 2 .

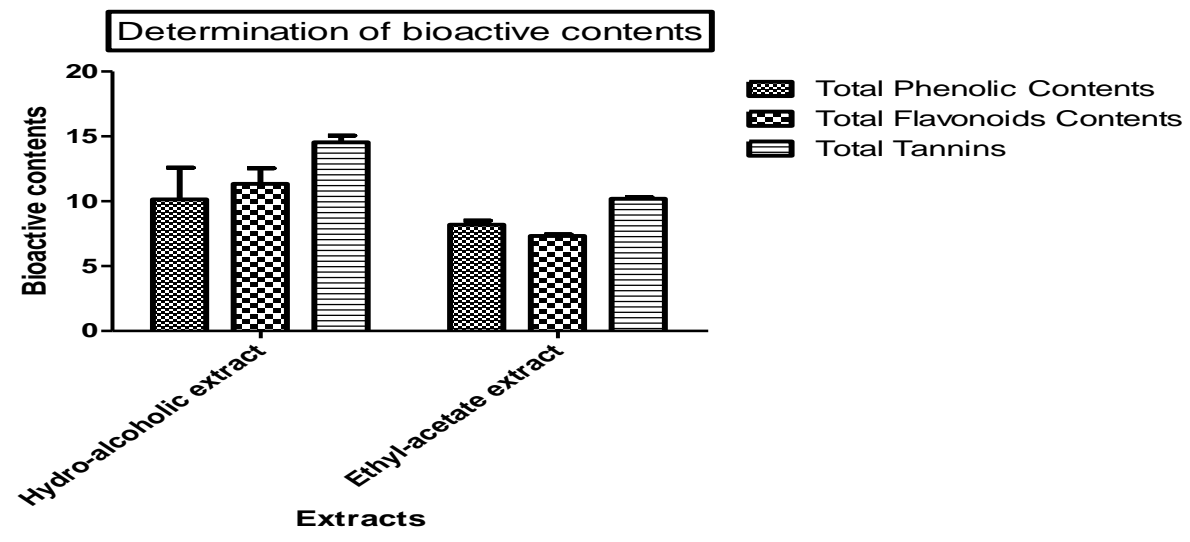

Figure 2: Total phenolic, total flavonoid \& total tannins contents of Saccharum munja 


\section{Anti-oxidant activity:}

The DPPH assay is one of the most commonly used methods for measuring antioxidant activity. The DPPH radical is widely employed in assessing free radical scavenging activity because of the ease of the reaction. The In-vitro free radical DPPH activity was found to $73.45 \pm 0.25$ at maximum concentration of $100 \mu \mathrm{g} / \mathrm{ml}$ shown in table 1 .

In the present study, the nitric oxide radical quenching activity of the polyphenolics extract was detected and compared with the standards Rutin and ascorbic acid. The NO methods revealed that the scavenging of the free radicals was found to be $57.20 \pm 1.15$ at maximum concentration of $100 \mu \mathrm{g} / \mathrm{ml}$ shown in table 2

\section{Statistical analysis}

The experimental results were expressed as mean \pm standard error of mean (SEM) of three replicates (Triplicate).

Table 1: In-vitro free radical scavenging activity of Saccharum munja Roxb. against DPPH model

\begin{tabular}{|l|l|l|l|l|l|l|}
\hline \multicolumn{3}{|c|}{ PLANT NAME } & \multicolumn{5}{c|}{ CONCENTRATION } \\
\hline S.N. & & $\mathbf{2 0}(\boldsymbol{\mu g} / \mathbf{m l})$ & $\mathbf{4 0}(\boldsymbol{\mu g} / \mathbf{m l})$ & $\mathbf{6 0}(\boldsymbol{\mu g} / \mathbf{m l})$ & $\mathbf{8 0}(\boldsymbol{\mu g} / \mathbf{m l})$ & $\mathbf{1 0 0}(\boldsymbol{\mu g} / \mathbf{m l})$ \\
\hline $\mathbf{1}$ & Hydro-alcoholic extract & $22.0 \pm 0.08$ & $38.37 \pm 0.040$ & $53.47 \pm 0.02$ & $65.0 \pm 0.04$ & $73.23 \pm 0.01$ \\
\hline $\mathbf{2}$ & Ethyl-acetate extract & $21 \pm 0.15$ & $30.45 \pm 1.54$ & $42.0 \pm 1.25$ & $56.5 \pm 1.10$ & $65.25 \pm 1.45$ \\
\hline $\mathbf{3}$ & Ascorbic acid (Standard) & $45.86 \pm 0.178$ & $63.78 \pm 0.156$ & $74.34 \pm 0.123$ & $82.79 \pm 0.149$ & $89.17 \pm 0.180$ \\
\hline $\mathbf{4}$ & Rutin (Standard) & $30.51 \pm 8.92$ & $42.05 \pm 5.61$ & $65.53 \pm 1.68$ & $79.98 \pm 6.39$ & $91.46 \pm 2.64$ \\
\hline
\end{tabular}

Table 2: Nitric oxide free radical scavenging activity of Saccharum munja Roxb.

\begin{tabular}{|l|l|l|l|l|l|l|}
\hline \multicolumn{2}{|c|}{} & \multicolumn{5}{|c|}{ CONCENTRATION } \\
\hline S.N. & PLANT NAME & $\mathbf{2 0}(\boldsymbol{\mu g} / \mathbf{m l})$ & $\mathbf{4 0}(\boldsymbol{\mu g} / \mathbf{m l})$ & $\mathbf{6 0}(\boldsymbol{\mu g} / \mathbf{m l})$ & $\mathbf{8 0}(\boldsymbol{\mu g} / \mathbf{m l})$ & $\mathbf{1 0 0}(\boldsymbol{\mu g} / \mathbf{m l})$ \\
\hline $\mathbf{1}$ & Hydro-alcoholic extract & $32.50 \pm 0.02$ & $45.17 \pm 0.050$ & $47.0 \pm 0.012$ & $53.0 \pm 0.042$ & $72 \pm 0.012$ \\
\hline $\mathbf{2}$ & Ethyl-acetate extract & $27.20 \pm 1.02$ & $37.20 \pm 1.10$ & $42.10 \pm 1.20$ & $46.0 \pm 0.50$ & $60.10 \pm 0.20$ \\
\hline $\mathbf{3}$ & Ascorbic acid (Standard) & $45.86 \pm 1.02$ & $63.78 \pm 1.20$ & $74.34 \pm 1.21$ & $82.79 \pm 1.30$ & $91.17 \pm 1.20$ \\
\hline $\mathbf{4}$ & Rutin (Standard) & $30.51 \pm 1.05$ & $42.0 \pm 1.12$ & $65.0 \pm 1.21$ & $79.0 \pm 1.20$ & $89.0 \pm 1.25$ \\
\hline
\end{tabular}

\section{CONCLUSION}

The results indicated a direct correlation between the antioxidant activity and the polyphenolics contents of the Sacchrum munja, which may the foremost contributors to the antioxidant activity of Sacchrum munja. On the basis of all finding the present study confirmed that $S$. munja are potential source of natural antioxidants.

\section{REFERENCES}

1. Shebek K, Schantz AB, Sines I, Lauser K, Velegol S, et al. The flocculating cationic polypetide from Moringa oleifera seeds damages bacterial cell membranes by causing membrane fusion. Langmuir. 2015; 31:4496-4502.

2. Feng Q, Wu J, Chen G, Cui F, Kim T, et al., A mechanistic study of the antibacterial effect of silver ions on Escherichia coli and Staphylococcus aureus. J Biomed Mater Res. 2000; 52:662-668

3. Anonymous. The Ayurvedic Formulary of India, Part (II), Ministry of Health and Family Welfare, Department of Indian System of Medicine and Homeopathy, Govt of India, New Delhi. 2000; 70-72

4. Augusto TR. et. al., Phenolic compounds and antioxidant activity of hydroalcoholic extracts of wild and cultivated murtilla (Ugni molinae Turcz.) Food Sci. Technol, Campinas.2014; 34(4):667-673.

5. Chaulya $\mathrm{NC}$ et al., In vitro free radical scavenging activity of methanol extract of rhizome of Cyperus tegetum Roxb.(Cyperaceae). Int J Curr Pharm Res, 2010; 2(3):39-43.

6. Saeed et al. Antioxidant activity, total phenolic and total flavonoid contents of whole plant extracts Torilis leptophylla L. BMC Compl Alter Med. 2012; 12:221.
7. Singh $\mathrm{R}$ et. al., Total phenolic, flavonoids and tannin contents in different extracts of Artemisia absinthium. $J$ Intercult Ethnopharmacol. 2012; 1 (2):101-104

8. Molyneux P. The use of the stable free radical diphenylpicrylhydrazyl (DPPH) for estimating antioxidant activity. Songklanakarin J. Sci. Technol., 2004; 26:211-219.

9. Rafat A., et al., Antioxidant potential and phenolic content of ethanolic extract of selected Malaysian plants. Res. J. Biotechnol.2010; 5:16-19.

10. Soares JR., et al., Antioxidant activity of some extracts of Thymus zygis, Free Radic. Res.1997; 26:469-478.

11. Amaeze OU. et al. Evaluation of antioxidant activity of Tetracarpidium conophorum (Müll. Arg) Hutch \& Dalziel leaves. Oxidative Med Cell Long. 2010; 7.

12. Duh PD, et al., Antioxidant activity of water extracts of Harng Jyur (Chrysenthemum morifolium Ramat) Lebnes wiss Technol. 1999; 32:269-277.

13. Balavoine GG, et al., Peroxynitrite scavenging by different antioxidants. Part 1: convenient study. Nitric oxide. 1999; 3(1):40-54.

14. Tsai PJ et al., Evaluation of NO-suppressing activity of several Mediterranean culinary spices. Food Chem Toxicol. 2007; 45(3):440-447.

15. Jagetia GC, et al., The Evaluation of Nitric Oxide Scavenging Activity of Certain Herbal Formulations in vitro: A Preliminary Study. Phytother. Res. 2014; 18:561-565,

16. Jagetia GC, et al. The Evaluation of Nitric Oxide Scavenging Activity of Certain Herbal Formulations in vitro: A Preliminary Study. Phytother. Res. 2004, 18:561-565,

17. Vriesman MF et alA method for measuring nitric oxide radical scavenging activity. Scavenging properties of sulfurcontaining compounds. Pharm World Sci. 1997; 19(6):283286. 